Mindsight 



\section{Colin McGinn}

\section{MINDSIGHT Image, Dream, Meaning}

Harvard University Press

Cambridge, Massachusetts, \& London, England (2004) 
Copyright (C) 2004 by the President and Fellows of Harvard College All rights reserved

Printed in the United States of America

Library of Congress Cataloging-in-Publication Data

McGinn, Colin, 1950-

Mindsight : image, dream, meaning / Colin McGinn.

p. $\mathrm{cm}$.

Includes bibliographical references and index.

ISBN 0-674-01560-6 (alk. paper)

1. Imagination (Philosophy) I. Title.

B105.I49M36 2004

$128^{\prime} .3-\mathrm{dc} 22 \quad 2004047473$ 